\title{
David Radek: Bolek V. Opolský (okolo 1400-1460). Život a legenda. Opava, Slezská univerzita v Opavě, 2018, ss. 310
}

Wciąż jeszcze wielu Piastów śląskich doby średniowiecza nie doczekało się spisania ich biografii. Stan ten jest wypadkową z jednej strony niewystarczającego zaangażowania historyków w śledzenie ich życiorysów, $\mathrm{z}$ drugiej strony zaś wynika z dużej liczby przedstawicieli śląskiej gałęzi piastowskiej, wyróżniającej się na tle pozostałych największym rozrodzeniem. Na przedstawienie w dalszym ciągu czekają więc m.in. interesujące sylwetki śląskich Piastów, których pozycja i znaczenie wykraczały nieraz poza granice krainy nad Odrą, wpisując się w szeroki kontekst dziejów naszej części Europy.

W 2018 roku opublikowana została biografia Bolka V opolskiego autorstwa czeskiego historyka Davida Radka. Fakt ten cieszy co najmniej z kilku powodów. Otrzymaliśmy przede wszystkim kolejną pracę poświęconą któremuś ze śląskich książąt, co jednak ważne - żyjącemu w XV wieku, gdy dotychczas biografistyka koncentrowała się przeważnie na okresie wcześniejszym. Ponadto jej bohater był bez wątpienia osobą ciekawą i nietuzinkową — kontrowersyjną dla jemu współczesnych, a budzącą również emocje długo po swojej śmierci. Na życiorysie Bolka V zaważyła oczywiście jego współpraca z husytami, przez którą przyległa do niego łatka kacerza i heretyka.

Pamięci o opolskim Piaście na przestrzeni wieków poświęcona została pierwsza część omawianej książki, zatytułowana Legenda. Zgodnie z licznymi przytoczonymi przez autora przykładami w kronikach $\mathrm{z}$ czasów średniowiecza była ona jednoznacznie negatywna, oparta na stereotypowym postrzeganiu zwolenników Jana Husa - do których zaliczano Bolka V - jako heretyków, a więc ludzi owładniętych pychą, fałszywych, będących zagrożeniem dla społecznego ładu. W dobie reformacji natomiast obraz ten nie był już tak jednoznaczny. Dla niektórych dziejopisarzy protestanckich Hus był 
poprzednikiem Marcina Lutra. Zmieniła się w związku z tym optyka postrzegania opolskiego Piasta, o którym, jeśli pisano, to w kontekście jego politycznych poczynań, nie ganiąc go przy tym za przystąpienie do husytów. Po dłuższej przerwie Bolkiem V zainteresowano się znów w XIX stuleciu. W atmosferze rodzącej się na Górnym Śląsku polskiej świadomości narodowej, mocno związanej z katolicyzmem, dla zaangażowanych $\mathrm{w}$ jej propagowanie autorów książę, jako odstępca od wiary polskiego narodu, stał się zdrajcą - ponownie więc postacią negatywną. Cieplej natomiast traktowała go, piórem niektórych polskich historyków, komunistyczna propaganda po drugiej wojnie światowej. Husytyzm postrzegała ona bowiem pozytywnie jako ruch rewolucyjny i przejaw walki klas, skierowany także przeciwko Niemcom, co z oczywistych względów odgrywało istotną rolę w powojennej Polsce. D. Radek w interesujący sposób wykazał zatem, że pamięć o bohaterze jego książki kształtowała się w zależności od zmieniającej się atmosfery religijnej oraz polityczno-społecznej postawy ludzi wypowiadających się o księciu.

Druga część pracy, zatytułowana Život, to przedstawiona w sposób chronologiczny biografia księcia. Autor wyszedł w niej od omówienia sytuacji politycznej księstwa opolskiego, począwszy od jego wejścia w 1327 roku w zależność od Królestwa Czech. Opisał aktywność młodego Bolka V u boku ojca, a także scharakteryzował kształt pierwotnie przyznanego mu władztwa. Kluczowym elementem biografii Bolka $\mathrm{V}$ jest oczywiście okres jego współpracy z husytami. Wskazując powody, które skłoniły do niej księcia, autor wykluczył, że sympatyzował on z ruchem husyckim, zanim taboryci wtargnęli zbrojnie na Śląsk. Przedstawił bowiem argumenty podważające odbycie przez Bolka V studiów w Pradze, już w trakcie których przesiąknąć miał on — jak dotąd sądziła część badaczy - ideologią husycką. Do walki u boku husytów skłonić miały go obawa przed zniszczeniem jego dzielnicy przez wojsko polne i chęć poprawy swojej nie najlepszej sytuacji finansowej. W tym charakterze również - finansowym, a nie religijnym - rozpatrzona została konfiskata przez Bolka V majątku kolegiaty w Głogówku, który posłużyć miał do odbudowy jego księstwa po zniszczeniach wojennych. Stosunek Bolka V do Kościoła i jego majątku, jak słusznie zauważono, nie różnił go od wielu innych średniowiecznych książąt. Na kolejnych stronach pracy przybliżone zostały aktywność Bolka $\mathrm{V}$ na tle wieloletniej rywalizacji o tron czeski po śmierci Zygmunta Luksemburskiego oraz stosunki księcia z władcami Królestwa Czech i Polski. Z opisu aktywności Bolka V wyłania się obraz człowieka o awanturniczym wprawdzie charakterze, dzięki któremu głównie zapisał się w pamięci, jednak nie tylko. Dostrzeżono także jego wzrastającą pozycję na Śląsku, przejawiającą się w poszerzaniu swojego terytorium, objęciu w gronie śląskich książąt funkcji starosty i występowaniu w roli pośrednika w sporach między władcami. 
Książka D. Radka to ważny głos w trwającej od średniowiecza próbie oceny Bolka V opolskiego. Wniosła przede wszystkim inne spojrzenie na okres jego współpracy z husytami, ukazała też, że oprócz posiadania awanturniczego usposobienia był również skutecznym politykiem. Jak podsumował autor, Bolko to typowy człowiek swoich czasów, lecz niewahający się wyjść poza ówczesne ramy mentalne i stawiający kontrowersyjne kroki dla osiągnięcia swych celów.

Tomasz Zawadzki

(iD https://orcid.org/0000-0001-8663-5477 Instytut Historii, Uniwersytet Śląski w Katowicach 